\title{
Harvest seasons and pruning management in pepper: production and pungency of the fruits
}

\section{Dalva Paulus; Ivan C Zorzzi; Fabiana Rankrape; Fabiana M Paula; Cláudia A Moura}

Universidade Tecnológica Federal do Paraná (UTFPR), Dois Vizinhos-PR, Brasil; dalvapaulus@utfpr.edu.br; dalvaufsmdeutch@yahoo. com.br (autor para correspondência); ivanzorzzi@gmail.com; fabianarankrape@gmail.com; fabianadepaula3@hotmail.com; claudiaamk@ yahoo.com.br

\begin{abstract}
Changes in plant architecture, such as apical pruning and harvesting at the right time, are management practices to obtain not only greater fruit production, but mainly quality and pungent fruits, preferred by the consumer market. We evaluated the effect of management of pruning and harvest seasons on growth, production and pungency of fruits conducted in the field. Nine seasons of harvest were studied $[90,101,116,131,146,161,176,191,206$ and 221 days after transplanting (DAT)] and two management systems (pruning and no pruning). The treatments were arranged in a factorial design (9x2) with split plot in a randomized block design with three replications. The agronomic traits analyzed were: height, chlorophyll, leaf area, soluble solids, number of fruits and pepper yield. The content of capsaicin and dihydrocapsaicin was determined using fruits harvested in two seasons (146 and 161 DAT) and in management systems (pruning and no pruning), in a factorial scheme (2x2), in a randomized complete block design with five replications. Growth and production traits did not differ significantly for pruning and no pruning managements, with an average of 71.8 fruits/plant and productivity of $429.7 \mathrm{~g} /$ plant. The agronomic traits were adjusted to the quadratic model. The maximum yield (529.09 g/plant) and the maximum number of fruits per plant (95.34) were estimated at 164.83 and 163.21 DAT, respectively. The use of pruning resulted in fruits with a higher content of capsaicin $(363.89 \mathrm{mg} / \mathrm{kg})$ and dihydrocapsaicin $(198.27 \mathrm{mg} / \mathrm{kg})$ at 161 DAT. Pruning management results in more pungent and better quality fruits for industry, and the maximum production of BRS Mari pepper was estimated at 164.83 DAT, important information for pepper producers, in order to schedule the harvests.
\end{abstract}

Keywords: Capsicum annuum, capsaicin, dihydrocapsaicin, plant architecture.

\section{RESUMO}

Épocas de colheita e manejo de poda na pimenta: produção e pungência dos frutos

Alterações na arquitetura da planta, como a poda apical e a colheita na época certa, são práticas de manejo que podem ser adotadas com a finalidade de obter não apenas maior produção de frutos, mas principalmente frutos de qualidade e pungência, preferidos pelo mercado consumidor. Objetivou-se avaliar manejo da poda e épocas de colheita sobre o crescimento, produção e pungência de frutos de pimenta, conduzida a campo. Foram estudadas nove épocas de colheita $[90,101,116,131,146,161,176,191,206$ e 221 dias após o transplantio (DAT)] e dois sistemas de manejo (poda e sem poda). Os tratamentos foram arranjados em esquema fatorial (9x2), com parcelas subdivididas, no delineamento blocos ao acaso, com três repetições. As variáveis analisadas das características agronômicas foram: altura, clorofila, área foliar, sólidos solúveis, número de frutos e produtividade de pimenta. $\mathrm{O}$ teor de capsaicina e dihidrocapsaicina foi determinado de frutos colhidos em duas épocas (146 e 161 DAT) e nos sistemas de manejo (com e sem poda), em esquema fatorial (2x2), no delineamento blocos ao acaso, com cinco repetições. Verificou-se que as variáveis de crescimento e produção não diferiram significativamente para o manejo com poda e sem poda, com valor médio de 71,8 frutos/planta e produtividade de 429,7 g/planta. As características agronômicas ajustaram-se ao modelo quadrático. A produção máxima de $529,09 \mathrm{~g} /$ planta e o número máximo de frutos por planta de 95,34 foram estimados aos 164,83 e 163,21 DAT, respectivamente. A utilização da poda resultou em frutos com maior teor de capsaicina $(363,89 \mathrm{mg} / \mathrm{kg})$ e dihidrocapsaicina $(198,27$ $\mathrm{mg} / \mathrm{kg}$ ) aos 161 DAT. Conclui-se que o manejo de poda resulta em frutos mais pungentes e de qualidade para indústria, e a época de produção máxima da pimenta BRS Mari estimada aos 164,83 DAT, informação de importância para o produtor de pimenta programar as épocas de colheita.

Palavras-chave: Capsicum annuum, capsaicina, dihidrocapsaicina, arquitetura da planta.

\section{Received on October 14, 2016; accepted on February 22, 2017}

$\mathrm{P}$ epper (Capsicum annuum) was the second most exported vegetable in Brazil, contributing $13.5 \%$ to the total value of exports (Agrianual, 2012). From the social point of view, pepper has great importance due to the great need for labor, mainly during harvest (Rufino \& Penteado, 2006). Dedode-moça pepper fits family farming models and the cultivation is carried out by small, medium and big producers (Carvalho et al., 2009).

The peppers of the genus Capsicum are from the United States, mainly from South and Central America (Crisóstomo 
et al., 2006). These peppers belong to the family Solanaceae, they are herbaceous plants with height that varies according to the species and growing conditions. The plant is used in several industrial sectors, for arthritis and muscle pain; in cuisine, peppers are mainly used as a condiment in natura, paste, dehydrated, sauces, spices and preserved. Moreover, it is a good source of vitamins A, C, E, B1, B2, phosphorus, potassium and calcium and they are also used in the manufacture of natural dyes (Reifschneider, 2000).

The Brazilian consumer market appreciates and characterizes peppers by the variability of shapes, color and pungency (Moreira et al., 2006). In this context, cultivar of pepper BRS Mari presents as a characteristic the high content of capsaicin, which gives pungent characteristic to the fruits, comparing to other pepper cultivar dedo-de-moça (Carvalho et al., 2009).

Pungency is an important commercial attribute and an important trait for fruit quality for fresh peppers, considering capsaicin content one of the main requirements to determine the commercial quality of the fruits, since it represents organoleptic, pharmaceutical properties, and burning sensation (Nwokem et al., 2010).

Changes in plant architecture, such as the apical pruning are management practices which can be adopted aiming to change source-drain relation aiming to obtain not only greater production of fruits, but mainly the fruit quality and pungency, preferred by the consumer market. Pruning consists of removing the apical gem, source of apical dominance, stimulating the axillary buds sprouting and consequently the lateral branching.

In Tabasco pepper cultivation, in Ceará, two prunings are carried out during the crop cycle, considering that the aim is to stimulate the formation of new branches, with proper distribution, improving the plant architecture and fruit distribution (Crisóstomo et al., 2006).

In literature studies on harvest seasons and pruning with development, production and pungency of pepper are scarce. In this study, the authors aim to evaluate the effect of pruning and different harvest seasons on growth, production and pungency of pepper, carried out in the field.

\section{MATERIAL AND METHODS}

The experiment was carried out in the experimental area at Universidade Tecnológica Federal do Paraná, Campus Dois Vizinhos, Paraná State, Brazil $\left(25^{\circ} 42^{\prime} \mathrm{S}, 53^{\circ} 06^{\prime} \mathrm{W}\right.$, altitude $\left.520 \mathrm{~m}\right)$. The local climate, according to Köppen classification, is Cfa type (Alvares et al., 2013). The soil of this area is classified as Eutrudox Red Latosol, clayey texture (Embrapa, 2006).

In order to determine the need for fertilization, soil samples were collected for laboratorial analysis and further interpretation, with no need for correction. The analysis showed the following characteristics for the $0-20$ cm layer: $\mathrm{pH}\left(\mathrm{CaCl}_{2}\right)=6.70$; organic matter $=53.61 \mathrm{~g} / \mathrm{dm}^{3} ; \mathrm{P}\left(\right.$ Mehlich $\left.^{-1}\right)=$ $13.78 \mathrm{mg} / \mathrm{dm}^{3} ; \mathrm{K}=1.33 \mathrm{cmolc} / \mathrm{dm}^{3} ; \mathrm{Ca}=$ $10.81 \mathrm{cmolc} / \mathrm{dm}^{3} ; \mathrm{Mg}=4.62 \mathrm{cmolc} / \mathrm{dm}^{3}$; $\mathrm{H}+\mathrm{Al}=2.47 \mathrm{cmolc} / \mathrm{dm}^{3}$.

The cultivar evaluated was BRS Mari. The authors reproduced this cultivar through seeds in polystyrene trays with 200 cells, containing commercial substrate Mecplant. The plants were transplanted with six definitive leaves, using spacing $1.2 \mathrm{~m}$ between plants and 1.0 between rows, totaling 8333 plants/ha.

Nine harvest seasons were studied, which corresponded to $90,101,116$, 131, 146, 161, 176, 191, 206 and 221 DAT and two management systems (pruning and no pruning). The harvest seasons were established based on previous studies carried out by Paulus et al. (2015). The treatments were arranged in a factorial scheme, in a split plot design, in randomized block design with three replications. The area of each plot (harvest season) was $40 \mathrm{~m}^{2}(5 \mathrm{x} 8$ $\mathrm{m})$, whereas the split plot (management) was $20 \mathrm{~m}^{2}(4 \times 5 \mathrm{~m})$. Each experimental unit consisted of four lines with a total of 16 plants. The useful area consisted of 8 plants, located in the center of the plot. Pruning consisted of removing of the apical bud of the branches, with the aid of pruning scissors, in two seasons: the first at 20 DAT and, the second, 15 days after the first season.

The evaluated agronomic traits were: plant height (using a measuring tape from the base of the plant to the longest branch); number of fruits and productivity per plant (sum of the mass of the fruits of eight central plants of the plot, obtained in all harvests, and then, division by the number of the plants of the experimental unit); leaf area [determined through the leaf discs method, according to the methodology proposed by Fernandes (2000)]; relative index of chlorophyll (RIC) a, b and total [determined using a portable chlorophyllometer (Falker), considering three readings per plant in leaves of the middle of the canopy, in 10 plants per plot] and soluble solids content (determined through a refractometry, a sample homogenizing the sample composed by fruits of three plants per plot in a domestic blender transferring two drops to the prism of the refractometer, with values expressed in ${ }^{\circ}$ Brix).

Capsaicin and dihydrocapsaicin contents, obtained from fresh fruits, harvested in two seasons (146 and 161 DAT), established according to Estrada et al. (1999) and in management systems (pruning and no pruning) in factorial scheme $(2 \times 2)$, in randomized block design with five replications. Analyses were carried out in Nature Lab Pesquisas e Análises, São Carlos, São Paulo. The analytical method used to determine capsaicinoids was based on the methodology proposed by Poyrazoglu et al. (2005).

The results of agronomic traits were subjected to analysis of variance, by $F$ test $(p<0.05)$, and to quantitative treatments (harvest seasons) were adjusted to regression models. For pungency, the authors used Tukey test $5 \%$ for separation of means. All the analyses were carried out with the aid of program "SAS Studio" (SAS Institute, 2014).

\section{RESULTS AND DISCUSSION}

BRS Mari pepper development occurred in a 315-day cycle, starting in 
September, 2012 and finishing in July 2013, and with frost occurrence. Full flowering ( $50 \%$ of open flowers) and the beginning of harvest were at 101 days after transplanting (DAT).

No significant interaction between pruning management and harvest seasons for the agronomic traits analyzed was noticed. Height and leaf area were not influenced by pruning, showing average values of $63.55 \mathrm{~cm}$ and $7.8 \mathrm{~m}^{2}$, respectively. In studies carried out by Marcelis (1996), the leaf area of pepper and tomato was not influenced by pruning of fruits or leaves, but it can be changed by the increase of the sunlight interception in the canopy, due to the change in plant density. Ambroszczyk et al. (2008), in studies, on eggplants, grown using different systems of pruning (one and two stems), report higher leaf area in plants grown with one stem, during vegetative phase. However, during fruiting no difference was noticed between the treatments. The authors justify this result due to the capacity of the eggplant to balance the assimilates in relation to pruning. Possibly the pepper presents this same characteristic, compensating the elimination of branches.

For height and leaf area, the authors noticed significant effects in the different seasons evaluated, with quadratic adjustment (Figures 1A and 1B). The maximum height growth $(143.68 \mathrm{~cm})$ was estimated at 284.58 DAT. The maximum leaf area, $7.93 \mathrm{~m}^{2}$, was estimated at 142.93 DAT, possibly due to an increase in number of leaves per plant, rather than individual leaf expansion (Sifola \& Barbieri, 2006). The increase of leaf area promotes an increase in the plant's ability to take advantage of solar energy aiming photosynthesis and, then it can be used as a parameter related to productivity (Gonzalez-Sanpedro et al., 2008).

Pagliarini et al. (2012) state that pepper plants showing higher heights are able to sustain a larger number of leaves, without damage on the structure, avoiding, for example, seedling damping-off. Moreover, these leaves may show higher leaf area, which enables luminous incidence, accelerating the photosynthetic processes essential to the plant development.

The authors verified that relative index of total chlorophyll did not show significant difference between pruning managements. The authors state that pruning did not influence the pigments which are responsible for photosynthesis. The relative index of total chlorophyll showed significant effect during the harvest seasons, with quadratic adjustment (Figure 1C). The maximum relative index of total chlorophyll, 68.45, was estimated at 104.17 DAT. Photosynthetic efficiency was related to the amount of chlorophyll and, consequently to the growth phase of the plant (Conceição et al., 1985). The authors noticed a decreasing behavior for relative index of total chlorophyll, possibly due to the plant senescence associated with the time of the year (autumn). In this sense, Gan \& Amasino (1997) report that leaf senescence can be initiated by intrinsic factors, just like plant age, reproductive development and time of the year.

According to Floss (2011), the leaf senescence of cultivated plants is associated with fruit and seed formation and, in many cases, it initiates with flowering, which explains the decreasing behavior for relative index of pepper plant chlorophyll, during flowering and fruit production. In studies on eggplant, species of the same family, Ambroszczyk et al. (2008) observed that the stem pruning of the eggplant did not show significant effect on the relative index of chlorophyll.

The number of fruits per plant (71.8), productivity per plant $(429 \mathrm{~g} /$ plant $)$ and soluble solids content $\left(9.05^{\circ} \mathrm{Brix}\right)$ were not influenced by pruning management. The results of this study corroborate the results obtained by Dasgan \& Abak (2003) who did not verify significant differences in pruning management for fruit size (length and diameter), matter and soluble solids of pepper cultivars Amazon and Balon.

The authors verified that the number and productivity of the fruits were influenced by harvest seasons, with quadratic adjustment (Figures 1D and 1E). Maximum number of fruits per plant, 95.34, was estimated at 163.21 DAT. At 164.83 DAT, the maximum productivity of $529.09 \mathrm{~g} /$ plant was estimated. During this time, the weather conditions, average temperature, were $19.4^{\circ} \mathrm{C}$, average monthly values for the net radiation, 748.70 $\mathrm{kJ} / \mathrm{m}^{2} / \mathrm{d}$ a y, favorable conditions for growth and production of peppers (Cruz \& Makishima, 2007). Temperatures lower than $12^{\circ} \mathrm{C}$ retard or inhibit plant development (Silva et al., 2005).

The result for cumulative production of all harvests (32.2 t/ha) found in this study is above the worldwide average productivity data for pepper of $15.2 \mathrm{t} /$ ha in 2012 (FAOSTAT, 2014). Despite the importance of these fruits, statistical information on production and commercialization of pepper in Brazil are scarce and the available data do not show the real economic situation, since large part of the production is commercialized in local markets and this commercialization is not part of the statistics (Domenico et al., 2012).

Soluble solids content was influenced by the harvest seasons, with quadratic adjustment (Figure 1F). The maximum soluble solids content, $9.92^{\circ}$ Brix, was observed at 149.2 DAT. Soluble solids content is used as an indirect measure of sugar content, increasing as the sugar levels increase, important indicative of the degree of fruit ripening (Chitarra \& Chitarra, 2005). In this study, the soluble solids content found in BRS Mari showed degree of maturity suitable for consumption and for industry which uses pepper for processing, in the form of pastes, jellies and preserved. According to Rêgo et al. (2009), soluble solid content is one important trait which determines the industrial yield of pepper. Lannes et al. (2007) evaluated 49 accessions of Capsicum chinense, and found soluble solids content which ranged from 6 to $10^{\circ}$ Brix.

For BRS Mari, the authors concluded that the plant begins flowering at 85 days after transplanting and the beginning of the harvest period at 101 days after transplanting; they also concluded that the harvests should be carried out within a 15-day interval, periods longer than this, fruit rot occurs. The nine harvest seasons evaluated were suitable for the pepper production cycle. The authors came to an interesting conclusion: in 


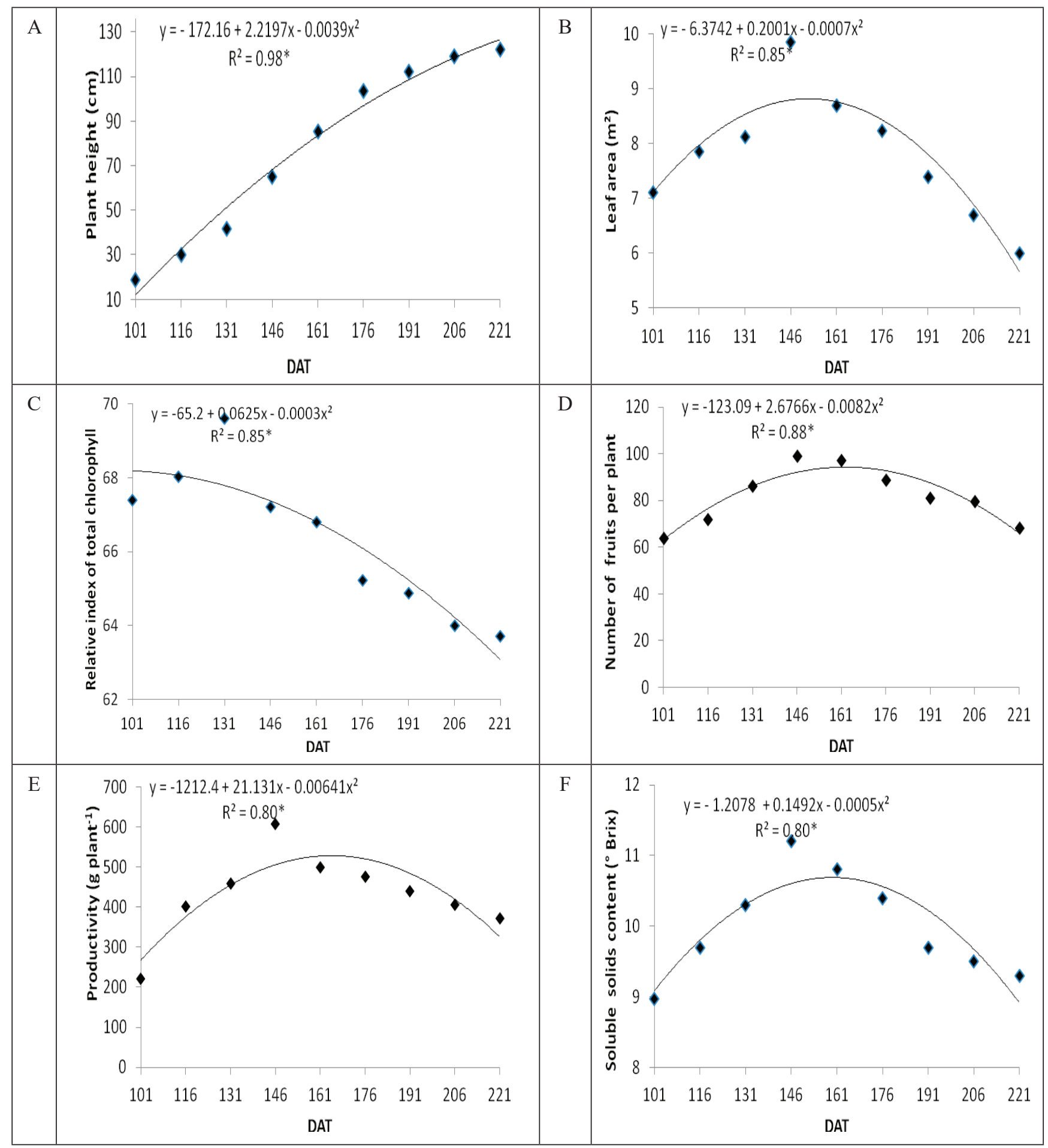

Figure 1. Plant height (A), leaf area (B), relative index of total chlorophyll (C), number of fruits per plant (D), productivity per plant (E) and soluble solids content (F) of pepper $\left({ }^{*} \mathrm{p} \leq 0,05\right)$. Dois Vizinhos, UTFPR, 2013.

regions where frost does not occur, pepper becomes a perennial plant.

Significant interaction between pruning management and harvest seasons was noticed. Pruning management changed significantly the fruit pungency, resulting in higher contents of capsaicin and dihydrocapsaicin (Table 1). In relation to the season, the authors verified that at $161 \mathrm{DAT}$, higher contents of capsaicin and dihydrocapsaicin could be noticed.

The results for contents of capsaicin and dihydrocapsaicin can be explained by the environmental condition, average of $19.4^{\circ} \mathrm{C}$, favorable temperature for the crop (Silva et al., 2005), age and maturation of the fruits during harvest season and by the influence of pruning management. Capsaicinoids are produced by secondary metabolism and this metabolism begins to intensify its functioning, from the stabilization of primary metabolism, justifying the 
Table 1. Average values of capsaicin and dihydrocapsaicin contents of BRS Mari pepper in pruning and no pruning management at different harvesting seasons conducted in the field. Dois Vizinhos, UTFPR, 2013.

\begin{tabular}{|c|c|c|c|c|}
\hline \multirow{3}{*}{ Management/season } & \multicolumn{2}{|c|}{ Capsaicin (mg/kg) } & \multicolumn{2}{|c|}{ Dihydrocapsaicin (mg/kg) } \\
\hline & \multicolumn{4}{|c|}{ Days after transplanting } \\
\hline & 146 & 161 & 146 & 161 \\
\hline Pruning & $252.05 \mathrm{Ba}^{*}$ & $363.89 \mathrm{Aa}$ & $158.54 \mathrm{Ba}$ & $198.27 \mathrm{Aa}$ \\
\hline No pruning & $242.48 \mathrm{Bb}$ & $320.10 \mathrm{Ab}$ & $139.00 \mathrm{Bb}$ & $188.71 \mathrm{Ab}$ \\
\hline Average & \multicolumn{2}{|c|}{294.62} & \multicolumn{2}{|c|}{171.13} \\
\hline CV $(\%)$ & \multicolumn{2}{|c|}{5.15} & \multicolumn{2}{|c|}{4.60} \\
\hline
\end{tabular}

*Averages followed by the same uppercase letters in lines and lowercase letters in columns do not differ, at $5 \%$ probability, Tukey test, $5 \%$.

increase of the capsaicinoids contents at 161 DAT, when the plant was physiologically mature, it means, the primary metabolism was stabilizing.

According to Moreira et al. (2009), the quantity of capsaicin in pepper is a quantitative trait, influenced by environmental conditions, such as time of the year, crop management and age of the fruit. In studies carried out by Estrada et al. (1999) in order to identify the influence of different harvest seasons and development stage of Padróntype pepper, the authors verified, in August and September, a significant increase of capsaicinoids (capsaicin and dihydrocapsaicin ), especially 42 days after flowering. The authors concluded that accumulation of capsaicinoids in pepper fruits was highly sensitive to environmental conditions. For BorgesGómez et al. (2010), capsaicin content is explained as a response for genotype $\mathrm{x}$ environment interaction.

Contents of capsaicin and dihydrocapsaicin indicate that, depending on the management system and harvest season, the fruits can be more or less pungent. The cultivar BRS Mari has great potential to be used for cayenne pepper production, since its high capsaicin content is important for refrigeration industry, which uses this pepper for producing sausage and companies which produce seasonings (Carvalho et al., 2009).

The capsaicinoids content varies among pepper cultivars. Domenico et al. (2012) evaluated accessions of Capsicum chinense with capsaicin contents ranging from 0 to $715 \mathrm{mg} / \mathrm{kg}$. Borges-Gómez et al. (2010), evaluating
C. chinense in different conditions of humidity and nutrition, obtained higher contents of capsaicin $(840 \mathrm{mg} / \mathrm{kg})$ and dihydrocapsaicin $(470 \mathrm{mg} / \mathrm{kg})$ at 126 DAT.

The authors concluded that pruning management did not influence the growth and the production of BRS Mari. The use of pruning resulted in fruits with greater pungency and higher industrial quality. Pepper fruits harvested at 161 days after transplanting showed higher contents of capsaicin and dihydrocapsaicin. The maximum productivity of fruits per plant was estimated at 164.83 days after transplanting, important information for pepper producer to plan growth, development and harvest season in accordance with the most favorable weather conditions and thus obtain productivities according to the productive potential of the cultivar.

\section{REFERENCES}

AGRIANUAL. 2012. Anuário da Agricultura Brasileira. São Paulo: FNP Consultoria e

Comércio. 303p.

ALVARES, CA; STAPE, JL; SENTELHAS, PC; GONÇALVES, JLM; SPAROVEK, G. 2013. Köppen's climate classification map for Brazil. Meteorologische Zeitschrift 22: 711-728.

AMBROSZCZYK, AM; CEBULA, S; KARA, AS. 2008. The effect of plant pruning on the light conditions and vegetative development of eggplant (Solanum melongena L.) in greenhouse cultivation. Vegetable Crops Research Bulletin 68: 57-70.

BORGES-GÓMEZ, L; CÁRDENAS, LC; NOVELO, JR; FREGOSO, MS; OREGEL, VR; COUOH, EV. 2010. Capsaicinoides en chile habanero (Capsicum chinense Jacq.) bajo diferentes condiciones de humedad y nutrición. Terra Latinoamericana 28: 35-41.

CARVALHO, SIC; RIBEIRO, CSC; HENZ, GP;
REIFSCHNEIDER, FJB. 2009. 'BRS Mari': nova cultivar de pimenta dedo-de-moça para processamento. Horticultura Brasileira 27: 571-573.

CHITARRA, MI; CHITARRA, AB. 2005. Póscolheita de frutos e hortaliças: fisiologia e manuseio. Lavras: ESAL/FAEPE. 785p.

CONCEIÇÃO, HEO; OLIVA, MA; LOPES, NF; ROCHA NETO, OG. 1985. Resistência à seca em seringueira. Pesquisa Agropecuária Brasileira 20: 1041-1050.

CRISÓSTOMO, JR; FURTADO, RF; ABREU, FR; CRISÓSTOMO, LA; MIRANDA, FR; BLEICHER, E; RODRIGUES, SMM; WEBER, OB; REIS, A; FILHO, RRR; GONDIM, RS; GIRÃO, EG. 2006. Cultivo de Pimenta Tabasco no Ceará. Fortaleza: Embrapa Agroindústria Tropical Fortaleza. 34p. (Boletim técnico, 3).

CRUZ, DMR; MAKISHIMA, N. 2007. Cultivo da pimenta - clima. Disponível em: http:/www. cnph.embrapa.br/paginas/sistemas_producao/ cultivo_da_pimenta/clima.htm. Acessado em 06 de agosto de 2013.

DASGAN, HY; ABAK, K. 2003. Effect of plant density and number of shoots on yield and fruit characteristics of pepper grown in glasshouses. Turkish Journal of Agriculture \& Forestry 27: 29-35.

DOMENICO, CI; COUTINHO, JP; GODOY, HT; MELO, AMT. 2012. Caracterização agronômica e pungência em pimenta de cheiro. Horticultura Brasileira 30: 466-472.

EMBRAPA - Empresa Brasileira de Pesquisa Agropecuária. 2006. Sistema Brasileiro de Classificação de Solos. 2. ed. Rio de Janeiro. 306 p.

ESTRADA, B; DIAZ, J; MERINO, F; BERNAL, MA. 1999. The effect of seasonal changes on the pungency level of padron pepper fruits. Capsicum and Eggplant Newsletter 18: 28-31.

FAOSTAT. 2014. Disponível em: <http://faostat. fao.org.>. Acessado em: 01 de março de 2014.

FERNANDES, PD. 2000. Análise de crescimento e desenvolvimento vegetal. Campina Grande: UFPB. 22p.

FLOSS, EL. 2011. Fisiologia das Plantas Cultivadas. Passo Fundo: UPF. 734p.

GAN, S; AMASINO, RM. 1997. Making sense of senescence - molecular genetic regulation and manipulation of leaf senescence. Plant Physiology 113: 313-319.

GONZALEZ-SANPEDRO, M C; TOAN, TLE; MORENO, J; KERGOAT, L; RUBIO, E. 2008. Seasonal variations of leaf area index of agricultural fields retrieved from Landsat data. Remote Sensing of Environment 112: 810-824.

LANNES, SD; FINGER, FL; SCHUELTER, AR; CASALI, VWD. 2007. Growth and quality of Brazilian accessions of Capsicum chinense fruits. Scientia Horticulturae 112: 266-270.

MARCELIS, LFM. 1996. Sink strength as a determinant of dry matter partitioning in the whole plant. Journal of Experimental Botany 47: 1281-1291.

MOREIRA, GR; CALIMAN, FRB; SILVA, DJH; RIBEIRO, CSC. 2006. Espécies e variedades de pimenta. Informe Agropecuário 27: 16-29.

MOREIRA, S; RODRIGUES, R; ARAÚJO, 
M; SUDRÉ, C, RIVA-SOUZA, E. 2009. Desempenho agronômico de linhas endogâmicas recombinadas de pimenta em dois sistemas de cultivo. Ciência Rural 39: 13871393.

NWOKEM, CO; AGBAJI, EB; KAGBU, JA; EKANEM, EJ. 2010. Determination of capsaicin content and pungency level of five different peppers grown in Nigeria. Science Journal 3: 17-21.

PAULUS, D; VALMORBIDA, R; SANTIN, A; TOFFOLI, E; PAULUS, E. 2015. Crescimento, produção e qualidade de frutos de pimenta (Capsicum annuum) em diferentes espaçamentos. Horticultura Brasileira 33: 091-100.

PAGLIARINI, MK; BISCARO, GA; GORDIN,
CRB; SANTOS, AM; BRANDÃO, JF. 2012. Níveis de fertirrigação na avaliação das características morfofisiológicas em mudas de pimenta malagueta. Irriga 17: 46-55.

POYRAZOGLU, ES; YEMIS, O; KADAKAL, C; NEVZAT, AA. 2005. Determination of Capsaicinoid profile of different chilli peppers grown in Turkey. Journal of the Science of Food and Agriculture 85: 1435-1438.

REIFSCHNEIDER, FJB. 2000. Capsicum: pimentas e pimentões no Brasil. Brasília: EMBRAPA. 113p.

RÊGO, ER; RÊGO, MM; FINGER, FL; CRUZ, CD; CASALI, VWD. 2009. A diallel study of yield components and fruit quality in chilli pepper (Capsicum baccatum). Euphytica 168: 275-287.
RUFINO, JL; PENTEADO, DCS. 2006. Cultivo da Pimenta. Informe agropecuário 27: 7-15.

SAS INSTITUTE. 2014. SAS Studio. Disponível em: http://www.sas.com/en_us/software/ university-edition.html//. Acessado em: $15 \mathrm{de}$ agosto de 2014.

SIFOLA, MI; BARBIERI, G. 2006. Growth, yield and essential oil content of three cultivars of basil grown under different levels of nitrogen in the field. Scientia Horticulturae 108: 408-413.

SILVA, ESA; SOUZA, CMA; ROCHA NETO, OG; FIGUERÊDO, FJC. 2005. Parâmetros bioquímicos de plantas de pimenta longa (Piper hispinervum C.DC.) em diferentes condições de cultivo no município de IgarapéAçu-PA. Revista Ciência Agrária 51: 171-189. 